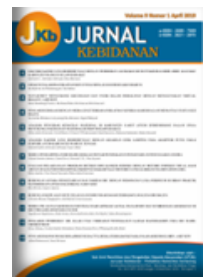

Volume 9 Nomor 2 (2019) 160-167

JURNAL KEBIDANAN

p-ISSN: 2089-7669; e-ISSN: 2621-2870

http://dx.doi.org/10.31983/jkb.v9i2.5240

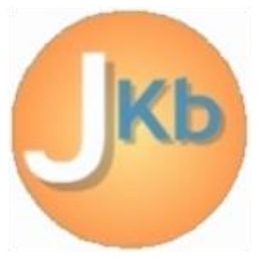

\title{
Water Kinetic Treatment as Standard Post Partum Care to Overcome Delayed Onset Muscle Sorness (Doms)
}

\author{
Bambang Trisnowiyanto ${ }^{1}$ Runjati $^{2}$ Emy Suryani ${ }^{3}$ \\ ${ }^{I}$ Department of Physiotherapy, Poltekkes Kemenkes Surakarta, Indonesia \\ ${ }^{2}$ Department of Midwifery Poltekkes Kemenkes Semarang, Indonesia \\ ${ }^{3}$ Department of Midwifery, Poltekkes Kemenkes Surakarta, Indonesia
}

Corresponding author: Bambang Trisnowiyanto

Email: trisnowiyanto@yahoo.co.id

Received: September 6th 2019; Revised: October 16th 2019; Accepted: October 24th 2019

\begin{abstract}
The process of labor through which the mother gives rise to the muscles due to the process of contraction, pain, and straining at the time of labor. Labor process cause muscle tension. Tension in the muscles that causes pain that requires the mother's help after delivery. Delayed onset muscle soreness DOMS is discomfort and pain in the muscles that result in a decrease in muscle strength, decreased joint motion (LGS) and damage to muscle tissue. The purpose of this study was to determine the effect of giving Water Kinetic Treatment to the reduction of DOMS in gastrocnemius muscle. This study was a two-group pre and post-test design that aims to find out how much influence the Water Kinetic Treatment has on reducing DOMS in normal postpartum, Water Kinetic Treatment is given 12 hours after normal parturition. Respondents were selected from the first postpartum gravida maternal patient with no complications after the normal parturition at salatiga Hospital which were for each group 6 mothers. Mothers wa given treatment for 4 days. Data were analyzed using paired t-test and independent t-test. Provision of Water Kinetic Treatment 12 hours after normal parturition did not affect the reduction in DOMS before and after the intervention ( $p>0.05$ ), but there was a significant influence between the group given water kinetic treatment therapy and the group that was not given to decrease DOMS ( $\mathrm{p}$ $<0.05$ ). There was a significant effect on the group given water kinetic treatment compared to the group not treated for a decrease in pain scale and increased muscle strength for 4 days of treatment.
\end{abstract}

Keywords: water kinetic treatment; post parturition normal; Delayed onset muscle soreness (DOMS)

\section{Pendahuluan}

Persalinan berhubungan dengan dua jenis nyeri yang berbeda. Pertama nyeri berasal dari otot rahim, pada saat otot ini berkontraksi nyeri yang timbul disebut nyeri viseral. Nyeri ini tidak dapat ditentukan dengan tepat lokasinya (Pain-Pointed). Nyeri viseral juga dapat dirasakan pada orang lain yang bukan merupakan asalnya disebut nyeri alih (Reffered pain). Pada persalinan nyeri alih dapat dirasakan pada orang yaitu punggung bagian bawah dan sacrum. Sedangkan nyeri yang kedua timbul pada saat mendekati kelahiran. Tidak seperti nyeri viseral, nyeri ini terlokalisir di daerah vagina, rectum dan perinium sekitar anus. Nyeri jenis ini disebut nyeri somatik dan disebabkan peregangan stuktur jalan lahir bagian bawah akibat penurunan bagian terbawah janin [1].

DOMS adalah suatu rasa yang tidak nyaman dan nyeri pada otot yang mengakibatkan terjadinya penurunan kekuatan otot, penurunan lingkup gerak sendi (LGS) dan terjadinya kerusakan pada jaringan otot [2]. Dari teori yang sudah dikemukakan DOMS disebabkan oleh mikrotrauma yang terjadi pada muscle fiber. DOMS dapat diklasifikasikan sebagai cedera pada otot tipe I. Sekitar 26,8\% kasus trauma pada olahraga adalah strain. Kasus ini sering terjadi 
karena gerakan olahraga yang salah ataupun beban yang terlalu berat sehingga merobek otot dan pembuluh darah kecil. Muscle soreness dapat terjadi pada fase akut (acute muscle soreness) yang berlangsung selama maupun setelah melakukan aktivitas fisik yang berat dalam jangka waktu cepat, kemudian muscle soreness dapat terjadi dan dirasakan setelah $6-24$ jam setelah melakukan aktifitas fisik. DOMS sering dikaitkan dengan keadaan yang tidak biasa, kerja otot yang berlebihan dan kontraksi eksentrik seperti downhill running atau lari menuruni bukit, plyometric, dan lain-lain. DOMS dapat diketahui dengan adanya nyeri tekan dan streching pada saat dilakukan palpasi dan gerakan. Nyeri tekan dapat terlokalisasi pada bagian distal otot [3]. Apabila DOMS tidak diberikan penanganan yang tepat akan menimbulkan cedera yang berkelanjutan sehingga dapat mempengaruhi aktivitas seseorang [3].

Banyak terapi yang dapat dilakukan untuk menangani nyeri pada otot atau DOMS diantaranya yaitu dengan farmakologi atau obat seperti NSID dan analgesik, dan fisioterapi. Intervensi fisioterapi yang dapat dilakukan dalam menangani DOMS yaitu Pooltherapy. Penggunaan air dingin dan air panas atau water kinetic dapat membantu memulihkan tubuh dengan cara meningkatkan aliran darah, merangsang sisten saraf pusat, mengurangi pembengkakan dan kekakuan, serta meningkatkan lingkup gerak sendi (LGS), mengurangi nyeri otot dan meningkatkan pembuangan sisa-sisa metabolism [4].

Berdasarkan paparan sebelumnya, maka rumusan masalah pada penelitian ini adalah : Penambahan Water Kinetic Treatment Pada Tindakan Standar Post Partum Normal Untuk Mengatasi DOMS?

Tujuan dari penelitian ini adalah (1) Tujuan umum adalah untuk mengetahui pengaruh water kinetic treatment pada kasus obstetric ginecology. (2) Tujuan khusus adalah untuk mengetahui pengaruh water kinetic treatment terhadap penurunan DOMS pada otot postural post partus normal.

\section{Metode Penelitian}

Rancangan penelitian ini adalah two group pre and post test design yang bertujuan untuk mengetahui seberapa besar pengaruh Water Kinetic Treatment terhadap penurunan DOMS pada post partus normal, Water Kinetic Treatment diberikan 12 jam setelah partus normal.
Hipotesis penelitian ini adalah terdapat pengaruh pemberian Water Kinetic Treatment terhadap penurunan delayed onset muscle soreness (DOMS) pada post partus normal. Penelitian ini akan dilaksanakan pada bulan Mei - Oktober di RSUD Salatiga Jawa Tengah dengan ethical clearance LB.02.02/1.3/583/2019.

Subyek penelitian ini adalah para ibu-ibu yang telah mengalami proses partus normal di RSUD Salatiga Jawa Tengah dengan tanpa ada komplikasi proses pasca partus normal.masingmasing kelompok sejumlah 6 ibu postpartum. Alat ukur yang digunakan pada penelitian ini adalah visual analogue scale (VAS) untuk mengetahui tingkat nyeri otot $12,24,36,48$ jam paska latihan yang menimbulkan DOMS. VAS adalah alat ukur nyeri dalam bentuk garis horisontal sepanjang 100 $\mathrm{mm}$ dengan range 0 s.d 100 dalam satuan milimeter. Ujung kiri garis tertulis "tidak nyeri" dan ujung kanan garis tertulis "nyeri tak tertahankan"

$\begin{array}{ccc} & \mathrm{X} & \mathrm{x} \\ \text { Tidak } & \text { Sangat } & \text { Nyeri } \\ \text { Nyeri } & \text { Nyeri } & \text { tak } \\ & & \text { tertahankan }\end{array}$

\section{Gambar 1}

Visual analogue scale (VAS) (Lau et al, 2013).

Variabel dalam penelitian ini antara lain : (1) variabel bebas (independent variable) yaitu Water Kinetic Treatment, (2) variabel terikat (dependent variable) yaitu DOMS pada ibu-ibu post partus normal.Delayed onset muscle soreness (DOMS) adalah suatu rasa sakit atau nyeri pada otot yang dirasakan antara $6-24$ jam setelah melakukan partus normal. DOMS akan memuncak sekitar 48 jam setelah partus dan akan menghilang $5-7$ hari setelah partus. Water Knetic Treatment (WKT) adalah metode terapi yang dilakukan didalam kolam untuk pemulihan DOMS yang timbul pada post partum normal. Intervensi WKT dilakukan dengan melakukan Gerakan - Gerakan di dalam kolam. Water Knetic Treatment adalah metode terapi yang dilakukan didalam kolam untuk pemulihan DOMS yang timbul pada post partum normal

Penelitian dilakukan dengan membagi secara acak (randomisasi) kelompok perlakuan dan kelompok kontrol, pengukuran DOMS dengan skala ukur VAS dilakukan 12 jam setelah partus normal, Water Kinetic Treatment pada kelompok 
perlakuan, pengukuran DOMS dengan skala ukur VAS dilakukan 24, 48 dan 72 jam setelah partus normal dan pada kelompok kontrol. Pengukuran DOMS dilakukan dengan mengintruksikan subjek untuk melakukan gerakan peregangan sesuai dengan intensitas nyeri yang dirasakan. Semua subjek pada penelitian ini diberi latihan eksentrik yang menimbulkan DOMS, lalu subjek dibagi menjadi dua kelompok secara acak. Kelompok I yaitu kelompok perlakuan dengan Water Kinetic Treatment, kelompok II yaitu kelompok kontrol atau tanpa perlakuan. Dosis dan keterampilan fisioterapis merupakan faktor yang dapat dikendalikan sedangkan aktivitas subjek dan medika mentosa atau pengobatan lainnya diluar perlakuan merupakan faktor yang sulit dikendalikan.

Setelah data pemeriksaan telah di kumpulkan sampai dengan akhir penelitian maka data dianalisa dahulu. Pertama ditentukan skala pengukuran variabel, data penelitian ini adalah skala numerik karena pengukuran DOMS menggunakan skala ukur visual analogue scale (VAS). Data dalam penelitian ini merupakan data berpasangan dan tidak berpasangan dengan rancangan penelitian two group pre and post test design, sehingga uji prasarat yang digunakan adalah uji normalitas..

Jenis hipotesis yang digunakan adalah komparatif numerik berpasangan lebih dari dua kelompok data dilakukan repeted anova dengan syarat memenuhi uji normalitas, apabila tidak memenuhi syarat maka digunakan alternatif uji friedman. Untuk uji hipotesis komparatif numerik tidak berpasangan lebih dari dua kelompok data dilakukan one way anova, apabila tidak memenuhi syarat maka digunakan alternatif uji kruskal wallis.

\section{Hasil dan Pembahasan}

Subyek penelitian dilakukan pengukuran skala nyeri menggunakan VAS untuk mengetahui tingkat nyeri yang dialami, baik pada keadaan sebelum perlakuan maupun setelah perlakuan. Data yang diperoleh dari pengukuran, kemudian diolah dengan statistik deskriptif untuk mengetahui rerata (mean), nilai maksimum, nilai minimum, dan standar deviasi. Data hasil pengukuran schober test sebelum perlakuan, baik kelompok yang diberi penambahan water kinetic treatment (Kelompok perlakuan) maupun yang tidak diberikan perlakuan apapun (Kelompok kontrol) pada tabel berikut ini,
Tabel 1

Sebaran Data Skala Nyeri Sebelum Perlakuan

\begin{tabular}{ccc}
\hline Variabel & Intervensi & Kontrol \\
\hline Mean & 0.9833 & 2.6625 \\
Nilai Minimum & 0,73 & 2,23 \\
Nilai Maksimum & 3,03 & 3,20 \\
Standar Deviasi & 0,45488 & 0,56208
\end{tabular}

Sumber: Data primer, 2018

Tabel 1 menunjukkan bahwa nilai rerata dari kedua kelompok berbeda pada jauh schober test kelompok perlakuan yaitu 0,9833 dan pada kelompok kontrol yaitu 2,6625. Schober test kelompok perlakuan memiliki nilai minimum 0,73 ; nilai maksimum 3,03 dan standar deviasi 0,45488 sedangkan nilai schober test kelompok kontrol memiliki nilai minimum 2,23; nilai maksimum 3,20 dan standar deviasi 0,56208.

Masing-masing kelompok terdiri dari 6 subyek, karena jumlah data yang dianalisis kurang dari 30 subyek maka dilakukan uji non parametrik [5]. Pengukuran 1 adalah pengukuran yang dilakukan pada hari ke 1 pasca persalinan normal, pengukuran 2 adalah pengukuran yang dilakukan pada hari ke 2 pasca persalinan normal, pengukuran 3 adalah pengukuran yang dilakukan pada hari ke hari ke 3 pasca persalinan normal dan pengukuran 4 adalah pengukuran dilakukan hari ke 4 pasca persalinan normal.

Tabel 2

Uji Pre dan Post Test Pada Kelompok Perlakuan

\begin{tabular}{ccc}
\hline Waktu & Sebelum & Sesudah \\
\hline 24 jam & 3,90 & 1,67 \\
48 jam & 2,32 & 1,10 \\
72 jam & 1,30 & 0,60 \\
96 jam & 0,00 & 0,00 \\
\hline
\end{tabular}

Tabel 2 menunjukkan data dari kelompok perlakuan yang dibandingkan sebelum dan sesudah diberikan water kinetic traetment. Dimana terdapat penurunan skala nyeri antara waktu 24 jam post partum normal yaitu dari skala nyeri 3,90 sebelum diberikan perlakuan menjadi 1,67 setelah diberikan perlakuan. Perlakuan pada jam ke 48 post partus normal skala nyeri 2,32 sebelum diberikan perlakuan menjadi 1,10 setelah diberikan perlakuan dan pada perlakuan pada jam ke 72 post partus normal skala nyeri 1,30 sebelum diberikan 
perlakuan menjadi 0,60 setelah diberikan perlakuan. Sementara setelah 96 jam post partus normal, rata-rata nyeri yang dialami pasien sudah menghilang. Rata - rata yang didapat berasal dari 6 pasien kelompok perlakuan yang dilakukan perlakuan water kinetic treatment selama 4 hari.

\section{Tabel 3}

Uji Pre dan Post Test Pada Kelompok Perlakuan dengan Paired Sampel T Tes

\begin{tabular}{ccccc}
\hline & Sebelum & Sesudah & $\begin{array}{c}\text { Perbedaan } \\
\text { rata }- \text { rata }\end{array}$ & $\begin{array}{c}\text { Sig } \\
(\mathrm{p})\end{array}$ \\
\hline Mean & $\begin{array}{c}1,88 \pm \\
1,64\end{array}$ & $\begin{array}{c}0,84 \pm \\
0,71\end{array}$ & 1,04 & 0,114 \\
\hline
\end{tabular}

Sumber: Data primer, 2018

Tabel 3 Sebelum dilakukan water kinetic treatment rata-rata tingkat nyeri 6 orang pasien yang diteliti selama 4 hari adalah 1,88 $\pm 1,64$ kemudian setelah dilakukan water kinetic treatment skala nyeri menjadi $0,84 \pm 0,71$. Setelah dilakukan analisis dan pengolah data diketahui bahwa perbedaan antara sebelum dan sesudah sebesar 1,04 dan hasil pengujian paired t test menunjukkan $\mathrm{p}>0,05$. Dengan demikikian dapat disimpulkan bahwa penggunaan water kinetic treatment tidak terbukti menurunkan DOMS pada post partus normal.

Tabel 4.3 menunjukkan bahwa pada kelompok yang diberikan water kinetic treatment perbedaan yang signifikan antara pre-test post test. Penelitian terhadap 15 subyek sehat, untuk mengetahui pengaruh water kinetic terhadap latihan squad jump. Dibagi dalam 2 kelompok yaitu kelompok perlakuan yang diberikan water kinetic treatment dengan kelompok kontrol ditemukan adanya peningkatan peningkatan pemulihan kekuatan isometrik yang signifikan pada 72 jam pasca latihan. Sementara untuk pemberian rendaman air hangat pasca latihan tidak memberikan perubahan signifikan pada peningkatan kekuatan otot, sama seperti tanpa perlakuan [6].

\section{Tabel 4}

Nilai Selisih Rerata Kelompok Perlakuan dengan Kelompok Kontrol

\begin{tabular}{cccc}
\hline Kelompok & Perlakuan & Kontrol & Sig $(\mathrm{p})$ \\
\hline Mean & 0,84 & 2,10 & 0,089 \\
\hline
\end{tabular}

Sumber : Data Primer 2018
Tabel 4 menunjukkan bahwa pada kelompok perlakuan memiliki rerata 0,84 dari 6 pasien post partus yang dilakukan perlakuan water kinetic treatment selama 4 hari dan rerata pengukuran pada kelompok kontrol sebesar 2,10 yang dilakukan pada 6 pasien post partus normal yang tdak mendapatkan perlakuan water kinetic treatment selama 4 hari. Dari hasil pengujian dengan menggunakan Independent Samples Test didapat hasil $\mathrm{p}$ sebesar 0,089 dimana $\mathrm{p}>0,05$ sehingga dapat disimpulkan jika penambahan water kinetic treatment lebih efektif untuk menurunkan nyeri akibat DOMS dibandingkan dengan tanpa perlakuan apapun.

Dari tabel diatas dapat disimpulkan bahwa terdapat perbedaan pengaruh yang signifikan secara statistik antara pemberian water kinetic treatment dengan tanpa memberian water kinetic treatment berdasarkan nilai rerata.

Hasil penelitian menunjukan tidak ada pengaruh water kinesthetic treatmen sebelum dan sesudah intervensi terhadap DOMS $(p>0,05)$, namun terdapat pengaruh yang signifikan antara kelompok yang diberikan terapi water kinetic treatmen dengan yang tidak diberikan terhadap DOMS ( $>>0,05)$.

Persalinan berhubungan dengan dua jenis nyeri yang berbeda. Pertama nyeri berasal dari otot rahim, pada saat otot ini berkontraksi nyeri yang timbul disebut nyeri viseral. Nyeri ini tidak dapat ditentukan dengan tepat lokasinya (Pain-Pointed). Nyeri viseral juga dapat dirasakan pada bagian otot lain yang bukan merupakan asalnya, disebut nyeri alih (Reffered pain). Pada persalinan nyeri alih dapat dirasakan pada bagian tubuh lain yaitu punggung bagian bawah dan sacrum. Sedangkan nyeri yang kedua timbul pada saat mendekati kelahiran. Tidak seperti nyeri viseral, nyeri ini terlokalisir di daerah vagina, rectum dan perinium sekitar anus. Nyeri jenis ini disebut nyeri somatik dan disebabkan peregangan stuktur jalan lahir bagian bawah akibat penurunan bagian terbawah janin [1].

Delayed onset muscle soreness (DOMS) adalah rasa sakit atau nyeri pada otot yang dirasakan $6-24$ jam setelah melakukan aktivitas fisik atau olahraga. Melakukan aktifitas fisik yang berlebihan dapat menyebabkan terjadinya cedera, kerusakan otot atau jaringan ikat pada (Cheung et al., 2003). Pada penelitian terdahulu menjelaskan adanya kerusakan ultrastructural dari myofilamens, terutama pada garis $\mathrm{Z}$ menjadi penyebab kerusakan pada jaringan ikat. Kerusakan jaringan ikat merupakan penyebab langsung terjadinya soreness, yang dapat menimbulkan 
peningkatan sensasi nyeri pada nosiseptor atau reseptor nyeri dan nyeri akan bertambah bila dilakukan stretching dan palpasi [3].

DOMS termasuk dalam strain atau cedera pada otot tipe I. DOMS dapat diketahui dengan adanya streching dan nyeri tekan yang terlokalisasi di bagian distal otot. DOMS sering terjadi pada saat pertama kali melakukan olahraga, olahraga dengan intensitas maupun frekuensi yang berlebihan dan apabila seseorang yang lama vakum terhadap aktivitas berat dan mengulang aktivitas berat di kemudian hari [3].

DOMS juga dapat disebabkan oleh aktifitas yang intens dan berat yang biasanya dicetuskan oleh gerak eksentrik, sehingga menyebabkan nyeri yang dapat menghambat aktivitas sehari-hari, menurunkan lingkup gerak sendi (LGS) dan nyeri lokal (3). Gejala-gejala yang menyertai DOMS meliputi bengkak, penurunan kekuatan dan daya ledak otot, nyeri lokal (Proske and Morgan, 2001). DOMS bisa timbul $6-24$ jam setelah latihan dan meningkat antara 48 jam kemudian dan akan menghilang $5-7$ hari setelah latihan [3]. Teori yang telah mendefinisikan terkait DOMS diantaranya: Teori asam laktat Teori asam laktat didasarkan pada asumsi bahwa asam laktat terus diproduksi setelah latihan dihentikan. Bagi masyarakat awam, akumulasi asam laktat dianggap menimbulkan DOMS. Namun, teori ini sebagian besar telah ditolak karena adanya tingkat metabolisme yang lebih tinggi terkait dengan kontraksi otot konsentris telah gagal menyebabkan DOMS. Selain itu, kadar asam laktat kembali ke tingkat seperti sebelum olahraga dalam waktu 1 jam setelah latihan. Oleh karena itu, asam laktat dapat menyebabkan rasa sakit akut akibat kelelahan setelah latihan intens, namun tidak dapat dikaitkan dengan timbulnya DOMS yang muncul $24-48$ jam setelah latihan [3]. Teori spasme otot Teori spasme otot mengamati timbulnya spasme otot saat istirahat setelah melakukan latihan eksentrik. Adanya peningkatan aktivitas otot yang berulang menyebabkan peningkatan tonus yang menyebabkan kompresi pembuluh darah lokal, ischemic dan penumpukan zat - zat nyeri [3]. Teori kerusakan jaringan ikat. Teori kerusakan jaringan ikat menjelaskan peran jaringan ikat yang membentuk selubung di sekitar kumpulan serat otot. Kandungan dan komposisi jaringan ikat berbeda antara jenis serat otot. Ketegangan jaringan ikat yang berlebihan dapat menyebabkan nyeri otot [3].

Teori kerusakan otot. Teori kerusakan otot yang pertama kali diajukan oleh Hough, berfokus pada terganggunya komponen kontraktil dari jaringan otot terutama pada tingkat garis $\mathrm{Z}$. Kerusakan mikroskopis yaitu ditandai adanya kerusakan sebagian atau bahkan total pada garis $\mathrm{Z}$ dan sarkomer. Kerusakan ini terjadi karena adanya peningkatan ketegangan disebabkan oleh penurunan motor unit aktif selama latihan eksentrik. Gangguan mekanis terhadap struktur elemen meningkat, terutama di antara serat tipe II dan garis Z. Nosieptor terletak di jaringan ikat otot dan di daerah arteriol, kapiler dan persimpangan musculotendinous juga dirangsang oleh sensasi yang menyebabkan rasa sakit. Pengukuran yang akurat pada teori ini menggunakan tes enzim darah yang diambil setelah melakukan latihan. Creatine kinase (CK) dianggap sebagai indikator permeabilitas membran yang dapat diandalkan karena enzim ini ditemukan secara eksklusif di dalam otot rangka dan otot jantung. Dengan demikian, gangguan garis $\mathrm{Z}$ dan kerusakan sarcolemma akan memungkinkan difusi enzim, seperti CK ke cairan interstisial. Pada kondisi istirahat biasa, tingkat CK plasma kira-kira 100 IU/L. Namun, setelah latihan eksentrik, tingkat CK yang beredar diketahui meningkat menjadi 40.000 IU/L. Hal ini menunjukan peningkatan yang signifikan terhadap permeabilitas sel membran otot yang mengikuti gangguan pada garis Z . Namun pada teori ini nampak perbedaan yang signifikan antara saat CK berada pada level puncak DOMS. Akibatnya, teori kerusakan otot ini hanya dapat diterima sebagian sebagai mekanisme permulaan terjadinya DOMS [3].

Teori peradangan didasarkan pada temuan bahwa respons inflamasi, yaitu edema dan infiltrasi sel inflamasi terjadi karena adanya gerak eksentrik otot yang berulang. Pada jaringan ikat dan serabut otot yang rusak terjadi akumulasi bradikinin, histamin dan prostaglandin serta terdapat kumpulan neutrofil dan monosit dilokasi cedera. Hal ini diikuti oleh masuknya eksudat dalam otot melalui peningkatan permeabilitas pembuluh darah kapiler. Pada akhirnya, terjadi tekanan osmotik dan menimbulkan nyeri.

Teori akumulasi kalsium ini dikemukakan oleh Guilick dan Kimura (1996) yang berasumsi bahwa kalsium yang biasanya tersimpan pada retikulum sarkoplasma akan terakumulasi pada otot yang terluka setelah terjadi kerusakan pada sarkolema. Hal ini mengarah pada penghambatan respirasi seluler pada tingkat mitokondria yang menyebabkan regenerasi ATP menjadi lambat. Selain itu, akumulasi kalsium juga diduga mengaktifkan protease dan fosfolipase sehingga menyababkan luka lebih lanjut pada sarkolema 
dengan adanya produksi leukotrien dan prostaglandin [3].

Dari beberapa teori yang memaparkan mekanisme terjadinya DOMS di atas, para peneliti sepakat bahwa satu teori saja tidak dapat menjelaskan mekanisme DOMS. Akibatnya, beberapa peneliti mengusulkan rangkaian mekanisme terjadinya DOMS dari gabungan beberapa teori. Para peneliti mengintegrasikan bahwa mekanisme awal terjadinya DOMS disebabkan karena kekuatan tarikan yang tinggi selama aktivitas kontraksi otot eksentrik, kerusakan jaringan otot dan kerusakan jaringan ikat. Lalu dilanjutkan dengan respon inflamasi akut yang terdiri dari pembentukan odema dan infiltrasi sel inflamasi.

Gaya tarik yang berlebihan selama aktivitas otot eksentrik menyebabkan kerusakan struktur protein pada serabut otot (terutama pada garis Z). Hal ini diikuti dengan ketegangan jaringan ikat (teori kerusakan jaringan ikat dan teori kerusakan otot). Kerusakan sarcolemma menyebabkan akumulasi kalsium yang menghambat respirasi seluler, produksi ATP terhambat dan homeostasis kalsium terganggu. Konsentrasi kalsium tinggi mengaktifkan enzim proteolitik yang menyebabkan penurunan garis $\mathrm{Z}$ pada sarkomer, troponin dan tropomiosin (teori akumulasi kalisum). Dalam beberapa jam terjadi peningkatan yang signifikan dalam sirkulasi neutrofil (teori peradangan). Komponen intraseluler dan penanda adanya kerusakan otot (misal $\mathrm{CK}$ ) berdifusi kedalam plasma dan cairan intrasisial. Zat ini berfungsi untuk menarik monosit antara $6-12$ jam yang kemudian berubah ke makrofag. Sel mast dan produksi histamin diaktifkan (teori peradangan). Lalu dalam beberapa jam terdapat peningkatan yang signifikan terhadap sirkulasi neurtofil pada lokasi cidera. Monosit atau magrofag akan meningkat jumlahnya pada saat 48 jam. Setelah terpapar lingkungan peradangan, makrofag menghasilkan prostaglandin yang mengiritasi ujung saraf aferen tipe III dan IV. Akumulasi histamin, potasium, kinin dari fagositosis aktif dan nekrosis seluler di samping tekanan tinggi dari edema jaringan dan suhu lokal yang meningkat kemudian mengaktifkan nociceptor dan menghasilkan sensasi DOMS.

Gerakan-gerakan Water Kinetic Treatmen (WKT), gerakan - gerakan yang digunakan meliputi: Water breath dance gerakan ini bertujuan untuk mengatur pernafasan dalam agar pasien merasa lebih rileks dan tenang. Gerakan water breath dance dilakukan dengan cara lengan atas fisioterapis menyangga occipitalis pasien, satu tangan yang lain memfiksasi punggung pasien lalu melakukan gerakan menaikan diafragma pasien. Gerakan dilakukan sebanyak 3 - 5 kali pengulangan per 1 sesi terdiri dari gerakan slow offering diberikan untuk tujuan rileksasi vertebra. Gerakan free spine diberikan dengan tujuan untuk mobilisasi vertebra. Gerakan accordion diberikan untuk tujuan fleksibilitas trunk. Gerakan rotating accordion diberikan untuk tujuan oscilasi trunk. Gerakan stilness diberikan untuk tujuan rileksasi tubuh secara general. Gerakan follow/explore move diberikan dengan tujuan untuk mobilisasi vertebra. Gerakan seaweed diberikan untuk tujuan mobilisasi vertebra secara gentle. Gerakan-gerakan tersebut memungkinkan akan menurunkan DOMS pada ibu postpartum setelah periode persalinan.

Cochrane (2004) melakukan study literary review yang mencangkup tentang berbagai penelitian tentang pengaruh contras therapy terhadap pemulihan cedera otot termasuk penururnan DOMS. Pada salah satu review diambil dari jurnal penelitian yang berjudul Effect of Whirlpool Therapi on the Sign and Simptoms of Delayed Onset Muscle Soreness. Pada penelitian tersebut terdapat 56 subjek yang terdiri dari 26 laki-laki dan 28 perempuan. Pada penelitian tersebut subjek yang telah mengalami DOMS pada otot lengan atas. Subjek terbagi menjadi empat kelompok yaitu kelompok terapi celup air hangat $\left(35^{\circ} \mathrm{C}-43,3^{\circ} \mathrm{C}\right)$, lalu kelompok celup air dingin $\left(12,8^{\circ} \mathrm{C}-18^{\circ} \mathrm{C}\right)$, kelompok celup air panas dingin $\left(38,9^{\circ} \mathrm{C}\right.$ dan $\left.12,8^{\circ} \mathrm{C}\right)$ dan kelompok kontrol atau tanpa penanganan. Pada terapi celup air hangat maupun pada terapi celup air dingin subjek diberi terapi selama 24 menit. Sedangkan pada contras bath terapi dilakukan selama 20 - 30 menit dengan mencelupkan 4 menit ke dalam air hangat dan 1 menit ke dalam air dingin. Hal itu diulangi hingga mencapai 20 - 30 menit. Terapi celup dilakukan sesaat setelah subjek melakukan latihan yang menyebabkan DOMS dan dilakukan terapi lagi pada saat 24 jam, 48 jam dan 72 jam setelah latihan. Dalam penelitian ini menggunakan alat ukur grapic pain rating scale (GPRS) yang terdiri dari $12 \mathrm{~cm}$ angka pada suatu garis. Penjelasan pada garis tersebut dimulai dari angka 0 yang berarti tidak nyeri hingga angka 12 yang berarti nyeri sangat amat tak tertahankan. Saat dilakukan pengukuran, dinyatakan bahwa kontas terapi dan terapi celup air dingin lebih efektif dari terapi celup air hangat [7].

Pada yang berjudul The Effect of Contrast Water Therapy on Symptoms of Delayed Onset Muscle Soreness, terdapat 4 subjek wanita dan 9 subjek pria yang telah diberi sejumlah latihan yang 
mencetuskan terjadinya DOMS, mereka dibagi menjadi dua kelompok secara acak yang terdiri dari kelompok perlakuan contrast water therapy dan kelompok kontrol. Contrast water therapy dilakukan dengan celupan air dingin $\left(8^{\circ} \mathrm{C}-10^{\circ} \mathrm{C}\right)$ selama 60 detik lalu dilanjutkan celupan air panas $\left(40^{\circ} \mathrm{C}-42^{\circ} \mathrm{C}\right)$ selama 120 detik (diulangi hingga 15 menit). Pada kedua kelompok dilakukan pengukuran DOMS menggunakan skala ukur VAS 24, 48 dan 72 jam setelah latihan eksentrik. Pada penelitian ini, didapatkan hasil bahwa Contrast Water Therapy efektif dalam penurunan Delayed Onset Muscle pada atlet[8].

Sebuah penelitian yang berjudul Automated Heating and Cooling Cycle for Muscle Recovery yang menggunakan mesin otomatis, peneliti mengatur suhu pada terapi panas $37^{\circ} \mathrm{C}-43^{\circ} \mathrm{C}$ sedangkan untuk suhu dingin $12^{\circ} \mathrm{C}-15^{\circ} \mathrm{C}$. Terapi panas dingin dengan mencelupkan anggota tubuh yang mengalami cidera pada bak pengatur suhu otomatis dilakukan sebanyak dua kali sehari, dimana perbandingan terapi celup panas dan dingin antara 3:1 sampai 4:1 yang dilakukan selama $20-$ 30 menit. Dalam penelitian ini, didapat hasil bahwa terapi celup panas dingin (contas bath) dalam bak pengatur suhu otomatis cukup signifikan dalam menangani cidera pada otot (strain) [9].

Water Kinetic Treatment baik digunakan dalam aspek promotif yaitu dapat membantu meningkatkan aktivitas fungsional pada wanita post partus normal.

Kelemahan dari penelitian ini adalah (1) Dari 12 subyek penelitian yang kemudian terbagi kedalam 2 kelompok sehingga hasil yang didapat pada penelitian ini belum bisa mewakili kelompok wanita post natal gravida pertama. Oleh karena itu, perlu penelitian lanjut yang melibatkan subyek lebih banyak dengan sebaran post partus gravida pertama, (2) sulitnya mendapatkan pasien post partus gravida pertama pasca 8 jam melahirkan, (3) sulitnya proses administrasi dan perijinan di lokasi pelaksanaan pelatihan.

\section{Simpulan}

Terdapat pengaruh yang signifikan pada kelompok yang diberikan perlakuan water kinetic dibandingkan kelompok yang tidak diberikan perlkaan terhadap penurunan skala nyeri dan peningkatan kekuatan otot yang dilakukan selama 4 hari perlakuan. Secara statistik terdapat perbedaan pengaruh yang signifikan antara kedua kelompok akan tetapi kelompok yang diberikan penambahan water kinetic treatment menunjukkan pengaruh yang lebih baik dari pada kelompok yang tidak diberikan perlakuan terhadap penurunan skala nyeri dan peningkatan kekuatan otot yang dilihat dari nilai rerata.

Kepada peneliti berikutnya: perlu dilakukan penelitian lebih lanjut mengenai penambahan water kinetic treatment pada tindakan standart post partus normal untuk mengatasi gejala delayed omset muscle sorness dengan jumlah subyek lebih banyak, perlakuan dilakukan kurang dari 24 jam pasca melahirkan secara normal agar mendapatkan hasil yang maksimal.

\section{Ucapan Terimakasih}

Ucapan terimakasih kepada ibu postpartum atas kesediaannya berpartisipasi dalam penelitian.Ucapan terimakasih pada Poltekkes Kemenkes Surakarta yang memberikan dana penelitian ini.

\section{Daftar Pustaka}

[1] Ratnaningsih, 2010. Perbedaan Tingkat Nyeri Pada Ibu Bersalin Primipara Kala 1 Fase Aktif sebelun dan Setelah di Berikan Kompres Panas Kering (Buli-Buli Panas) di Rumah Bersalin Siti Khodijah Kabupaten Tegal (Skripsi). Semarang: Universitas Muhammadiyah Semarang.

[2] Rakasiwi, Andung Maheswara, 2014. Aplikasi Ice Massage Sesudah Pelatihan Lebih Baik Mengurangi Terjadinya DOMS Daripada Tanpa Pemberian Ice Massage Pada Otot Hamstring. Jurnal Ilmiah Fisioterapi, Ikatan Fisioterapi Indonesia, hal. 25 - 36.

[3] Cheung, Karoline, et al, 2003. Delayed Onset Muscle Soreness Treatment Strategies and Performance Factors. Sports Med 2003; 33 (2): 145-164

[4] Mustofa, Surendra, Mulyani., Kinanti, Rias Gesang, 2014. Pengembangan Pelatihan Fisioterapi Contrast Bath dengan Media Video pada Mahasiswa Ilmu Keolahragaan. Fakultas Ilmu Keolahragaan Universitas Negeri Malang. Jurnal Sport Science, Volume 4, Nomor 1, hal. $12-21$.

[5] Hastono SP. SobriL. 2011. Statistik Kesehatan. Jakarta : Raja Grafindo Persada

[6] Proske U, Morgan DL. 2001. Muscle damage from eccentric exercise: mechanism, mechanical signs, adaptation and clinical applications. J.Physiiol. Dec 1;537(Pt 2):33345.

[7] Kuligowski, et al, 1998. Effect of whirpool 
on the sign symptoms of delayed onset muscle soreness. Journal of Athletic Training, hal $222-228$.

[8] Vaile, Joanna, Halson, Shona, Gill, Nicholas, 2008. Effect of hydrotherapy on the sign symptoms of delayed onset muscle soreness. Eur J Appl Physiol, hal 447 - 455
[9] Yasin NSM, Nassir M. 2013 Bed Massage: Automated Heating and Cooling Cycle for Muscle Recovery Bed Massage: Automated Heating and Cooling Cycle for Muscle Recovery . EURECA . 115-116 